\title{
Evidence-Based Practices of Promoting Entrepreneurship Education in Higher Education Institutions
} in Africa

\author{
${ }^{1}$ Fawzy Basardien, ${ }^{2}$ Chris Friedrich, ${ }^{1 *}$ Michael Twum-Darko \\ ${ }^{1}$ Cape Peninsula University of Technology, Cape Town, South Africa \\ ${ }^{2}$ University of the Western Cape, Cape Town, South Africa \\ fawzybasardien@yahoo.com, cfriedrich@uwc.ac.za, ${ }^{*}$ darkom@cput.ac.za
}

\begin{abstract}
This research applies the changing of cognitive mechanisms of University students through Entrepreneurship Education (EE). The study hypothesises that entrepreneurial orientation (achievement orientation, personal control, innovation and self-esteem) improves after completing the entrepreneurship module. The context of this research involves undergraduate commerce students from the University of the Western Cape (UWC) in South Africa. The study involves quantitative research using questionnaires through a longitudinal approach. The research design consists of a pre-test, post-test and post-test after the intervention. The impact of the training intervention was assessed over a 12 month period based on a randomised control design. This study indicates that entrepreneurial orientation was influenced through this Entrepreneurship module. The practical implications of this study emphasises the importance of training approaches that are based on empirical research. The uniqueness of this paper lies in the pedagogy used that allows the effectiveness of assessing a training program.
\end{abstract}

Keywords: Entrepreneurial Action, Entrepreneurial Orientation, Achievement Orientation, Innovation, SelfEsteem, Personal Control, Higher Education

\section{Introduction}

Slow economic growth in most African countries have led to job creation challenges and as such there are no job guarantees, in particular, for University graduates at the end of completing a degree. In South Africa, this is against the backdrop of rising cost of University education. According to the National Development Plan more than 10 million jobs are expected to be created where a large part of it needs to come from new entrepreneurial ventures (Jenvey, 2015). Entrepreneurship is therefore crucial for the on-going development of the country as well as innovating new products and services. South African universities have not placed sufficient importance on entrepreneurship education resulting in entrepreneurship being the less explored career path. Poor perceptions of entrepreneurship are driven by convictions already developed at school level that it is not a viable career option as opposed to obtaining employment. Entrepreneurship Education (EE) pedagogies have therefore not evolved sufficiently to improve Entrepreneurial Orientation (EO), particularly of commerce students. As a result the impact of EE in South African Universities is very low in contrast to other African Universities. South Africa has approximately one and a half million informal small and medium business enterprises (SMMEs) the bulk of which employs less than 50 employees (Statistics South Africa, 2015). This raises many questions relating to EE at Universities, specifically the scanty focus on improving existing curricula and secondly, the low level of start-up activity of graduate students. Although (EE) is growing speedily in higher education globally and the fact that governments tend to fully support it, proactive models are needed in order to ensure a better throughput of potential entrepreneurs. There is a lack of empirical studies that demonstrate how EE helps to create more entrepreneurs. The current literature reflects positive and negative reviews of EE in African Universities. This paper will review the HYTTI Model for Entrepreneurship programs at a South African (SA) University and how it influenced EO of commerce students.

\section{Literature Review}

The necessity of Entrepreneurship: With respect to the wide range of definitions one can deduce that an entrepreneur is an individual who innovates new composites of production factors as demonstrated through 
new approaches of communication, improved services, and new markets, as well as determining new sources of supply; or an individual with a higher risk profile by exploring market opportunities, contributing to the elimination of imbalance between supply and demand; or an individual who operates his/her own business (Kalitanyi \& Visser, 2010). One of the primary indicators used in the Global Entrepreneurship Monitor (GEM) to measure entrepreneurial growth is the total entrepreneurial activity index (TEA). TEA includes individuals in the process of having started a business as well as those operating a new business less than $31 / 2$ years old. South Africa has shown a low TEA consistently over the past decade (Singer, Amaros \& Moska, 2014). An education system that contributes to an increase in start-up activity is therefore critical for TEA. Academics find the measuring of entrepreneurial growth to be a critical area in entrepreneurship research. The extended and keen interest in entrepreneurship is prompted by many factors: some include a means of stimulating stagnated economies; stimulating developing economies and coping with unemployment challenges by providing new employment opportunities. In developing economies, such as South Africa, entrepreneurship is seen as a means of promoting economic development, employment creation and social upliftment (Brijlal, 2011).

Human Capital Theory: As argued by Unger, Rauch, Frese (2009), Brijlal (2011), Martin, McNally \& Kay, (2013), many studies focusing on entrepreneurship research have included human capital theory in their predictor models. The lack of employment opportunities for many students in South Africa prompted the University of the Western Cape (UWC) to introduce Entrepreneurship as a subject at second and third year levels (Friedrich \& Visser, 2006). Over the years EE at Universities generally have not produced a significant increase in start-up enterprises and many researchers have been drawn to understand this phenomena. In terms of the generally accepted obligations of Universities the core focus is on teaching, research and technology transfer, more so in EE programs. Most of the empirical studies reviewed indicate that EE can enhance entrepreneurial skills, competencies and attitudes (Ronstadt, 1987; Braukmann, 2000; Hisrich, Peters \& Shepherd, 2002; Timmons \& Spinelli, 2004; Siteman, 2004; Green, Katz \& Johannison, 2004). The specific purpose of this program is to capacitate students sufficiently to become future entrepreneurs. With similar programs offered in other major tertiary institutions how do tertiary institutions understand the concept of human capital in an EE context?

Human capital in the entrepreneurship literature is often operationalised by the level and type of education of the founding entrepreneurs (Urban \& Congo, 2015). Contemporary research involving human capital includes work experience, Entrepreneurship experience, general skills, father's/mother's background and expertise. Recent studies involving human capital established that entrepreneurs with superior knowledge, expertise and skills attain higher performance (Martin et al., 2013). Effective human capital formation through EE has become important to governments globally. Gleaning from the literature limited research is available demonstrating the effectiveness of EE to produce more or better entrepreneurs. However, in a recent study there was support for the significance of EE and effective human capital (Martin et al., 2013). Their study established significance between human capital and entrepreneurial intention. The study indicates that the relationship between $\mathrm{EE}$ and entrepreneurial intention is more significant in an academic environment compared to a general training environment. These findings have significant practical implications. Governments globally will have a greater understanding of the content when considering forthcoming budgets related to EE and training. Second, these findings propose that future training program content can be improved which may benefit students by improving financial success over time (Martin et al., 2013). In Unger et al. (2009) study significance was established in human capital-success relationship ( $\mathrm{r}=$ .098). Unger et al. (2009) study established that the use of knowledge/skills rather than education/experience in human capital indicated that emerging firms achieved a superior performance compared to established firms. These findings suggest that the human capital is not static and that the focus of research should rather be on learning processes and conversion of skills/knowledge to entrepreneurial action (Unger et al., 2009).

In Urban \& Congo's (2015) study a cross-sectional research design was used to investigate the relationship between human capital comprising of education, work experience and business performance of $\mathrm{N}=126$ entrepreneurs of retail SMEs in the Democratic Republic of Congo. The study concluded that human capital is correlated to levels of education of the founder and employees which in turn positively influences business performance. Taking this into consideration human capital facilitates greater efficiency by the entrepreneur 
to convert entrepreneurial effort into commercialisation. Previous experience increases the owner-managers' entrepreneurial attentiveness, increase preparedness to determine opportunities. Prior business experience has been linked to assets like extended networks, increased know-how and a solid reputation with investors, customers and suppliers.

Action Strategy Theory: As mentioned previously it is not always clear how EE can lead to new start-up businesses. Contemporary theories suggest that the motivation guides the pursuit of business opportunities through actions taken by the entrepreneur (Bird \& Schjoedt, 2009; Shane, Locke, \& Collins, 2012). Some perspectives suggest that the previous dispensation in South Africa created an education system where the focus was on producing individuals who would rather be job seekers rather than for themselves. The resultant effect of such approaches created an environment where University graduates failed to become selfreliant and instead pursued careers in large corporations (Nicolaides, 2011). Entrepreneurship researchers emphasized that concept of action is a principal construct in understanding entrepreneurial behaviour (Baron, 2007a:2007b; McMullen \& Shepherd, 2006). As Nicolaides (2011) points out the predominant system continues to be biased toward producing individuals who prefer to seek a job after graduating from Universities. Given the focus of action in EE as well as new career options in Entrepreneurship, an obvious question presents itself in relation to the best approach to teach entrepreneurial action (Edelman, Manolova, \& Brush, 2008; Neck \& Greene, 2011). Action-based Entrepreneurship training has emerged as an effective method to develop students (Åsvoll \& Jacobsen, 2012; Barr, Baker, \& Markham, 2009; Fiet, 2001; Gorman, Hanlon, \& King, 1997; Honig, 2004; Oosterbeek, van Praag, \& Ijsselstein, 2010; Pittaway \& Cope., 2007; Rasmussen \& Sorheim, 2006).

Action principles are derived from applied psychology and provide knowledge about how to do something (Frese, Bausch, Schmidt, Rauch, \& Kabst, 2012). This perspective regarding EE acknowledges the importance of both action and theory to ensure more start-ups. As various models pertaining to EE continue to evolve more research is needed to understand the short- and long-term effects of Entrepreneurship training. More scholars have noted that there are several issues that previous research has not adequately addressed (Martin et al., 2013). The study concluded that many evaluation studies focusing on EE have inconsistent theoretical grounding and more studies which develop a better theoretical contribution of Entrepreneurship training are needed (Martin et al., 2013). Generally, research studies are inclined to focus on short-term effects, such as knowledge, intentions and attitudes, or only on long-term outcomes, such as start-up or survival. The study evaluated the training in a randomized controlled field experiment. The 12-month evaluation study showed that the training had a significant impact on business start-ups: the likelihood of students in the training group was more likely to start a new business than students in the control group (Gielniek et al., 2015).

Entrepreneurship Education Models: Alarape (2008) drawing from the works of Ronstadt, 1990; Streeter, Jaquette \& Hovis, 2002; and Blenker, Dreisler, Færgemann \& Kjeldsen, 2004 has explored various methodologies and models of EE. These studies refer to three models of EE: composite, integrated and network models. The composite model involves courses presented from traditional academic departments typically at higher education institutions. The content typically includes SME management, taxation for SMEs, financial management, business management and computing. The composite model appears to be predominant in University curricula where the emphasis is placed on basic principles in Entrepreneurship. These introductory principles comprise the basic elements of Entrepreneurship in relation to the economy and the importance of the contribution of entrepreneurs in the global economy. Under the composite model the courses are typically presented by individuals who has never owned a business before and whose interest may lie elsewhere. In addition, one may find that because these lecturers/tutors may never have operated or started a business before they lack the practical skills that are a core requirement. This limitation in this particular model is addressed by the integrated model.

The approach of the integrated model is based on the delivery of the program through a specialised department or centre for Entrepreneurship studies. The content of the program comprises of entrepreneurial orientation; life skills; innovation; overcoming challenges; opportunity recognition skills; business assessment skills; business start-up skills; business strategy; environmental assessment skills; ethics; negotiating skills; networking skills; and harvesting skills (Ronstadt, 1990). With this model students are 
enrolled for the introductory business school courses as well as core modules. The key feature of this model is the fact that the modules are coordinated by a dedicated unit. The network model is based on a wider collaborative effort and includes two or more Universities. With this approach greater synergy is obtained through economies of scale. The network model has become progressively prevalent due to the declining resources and the growth in the number of learners in Entrepreneurship studies. For example, there is a paradigm shift in EE pedagogies where increasing focus is placed on converting entrepreneurial skills into business start-ups. The advent of reviewing EE curricula/pedagogies through the revision of the network model marks a fresh approach in higher education. However, as with any new approaches a number of administrative and practicality challenges are presented relating to allocation of budgets among collaborating institutions (Blenker et al., 2004).

Given the above introduction, the following hypotheses were used to measure changes in components of entrepreneurial orientation in a longitudinal design:

Hypothesis 1 - achievement orientation in the training group improves after attending the training module; Hypothesis 2 - personal control in the training group improves after attending the training module; Hypothesis 3 - innovation in the training group improves after attending the training module; Hypothesis 4 - self-esteem in the training group improves after attending the training module; Hypothesis 5 - achievement orientation, personal control, innovation and self-esteem in the control group declines as a result of not participating in the training module;

Hypothesis 6 - there is a difference between the training and control group for locus of control after attending the training module;

Hypothesis 7 - there are differences between students who have parents who are self-employed and those who are employed concerning the variables achievement, innovation, locus of control and self-esteem;

\section{Methodology}

Research Method: Drawing from Crotty (2003:10), Guba \& Lincolin (1989:83), the ontological stance of this study was one of objectivism as certain indicators of the phenomenon - Evidence-Based Practices of promoting entrepreneurship education in Higher Education Institutions in Africa - were perceived as social constructs but with very little clarity available. As such the epistemology stance of this research was firmly grounded in the ontological belief that the entrepreneurial skill of the students is a manifest of entrepreneurship education and training. Given this philosophical assumption, the study employed a research design of a pre-test (T1) and a post-test (T2) in conjunction with a non-randomised control group. In order to effectively measure the influence of the training the research involved a longitudinal study design where students of the experimental and control group were tested at the start of the academic period as well as at the end. Over the past few decades a number of questionnaires have been developed to measure entrepreneurship development (Wickham, 2004). The questionnaire used in this study is based on previous research conducted in Africa involving success factors in entrepreneurship (Frese et al., 2007: 2009; 2012). In line with such studies and in particular, studies involving entrepreneurship and personality, four constructs have emerged and have been used consistently in entrepreneurship research. The experimental group which participated in T1 and T2 consisted of $\mathrm{N}=69$ 2nd year students while the control group N $=45$ students who did not participate in any EE program for the period.

Table 1: Study Design

\begin{tabular}{llll}
\hline & T1 - before training & Intervention & T2 - 10 months after \\
\hline Training group & 0 & Entrepreneurial training & 0 \\
Control group & 0 & No training & 0 \\
\hline
\end{tabular}

Note: 0 = Evaluation measures collected

Sample Selection: We used class lists of registered students from the Commerce Faculty and randomly assigned students to the training or the control group. The training group consisted of 69 participants $(\mathrm{N}=$ 69) second year students and were registered for the entrepreneurship program. The control group consisted of 45 participants $(\mathrm{N}=45)$ second year students and were not involved in entrepreneurship training at all. The control group were essentially comprised of students from the Economics Department. Table 2 below 
provides an illustration of the sample of the training and control group as well as the breakdown in relation to gender.

Table 2: The Sample

\begin{tabular}{|c|c|c|c|c|c|}
\hline Group & Frequency & Percent & Control group & Frequency & Percent \\
\hline Experimental group & & & Male & 15 & 33.3 \\
\hline Male & 25 & 36.2 & Female & 27 & 60 \\
\hline Female & 36 & 52.2 & Missing & 3 & 6.7 \\
\hline Total & 61 & 88.4 & Total & 45 & 100 \\
\hline Missing & 8 & 11.6 & & & \\
\hline Total & 69 & 100 & & & \\
\hline
\end{tabular}

Measures: Over the past few decades numerous measuring instruments have been developed in order to study and measure entrepreneurial orientation. In line with contemporary research and focusing on personality and entrepreneurship, four factors have been used. These factors include need for achievement, locus of control, innovation and self-esteem (Robinson, Stimpson, Huefner \& Hunt, 1991a). These factors were measured with 5 point Likert scales. Several studies have associated education and training to entrepreneurial success involving the aforementioned factors (Kiggundu, 2002; Singer et al., 2014). In order to examine and to predict the effectiveness of entrepreneurship training at University level this instrument is based on Entrepreneurship attitude orientation (EAO) developed by Robinson et al. (1991). Attitude theory therefore suggests that the EAO measuring instrument is a good predictor of Entrepreneurship. EAO was also developed to predict the three elements of attitude (learning to understanding Entrepreneurship, learning to become entrepreneurial and learning to become an entrepreneur) instead of focusing on personality theory.

The four measures included need for achievement, locus of control, innovation and self-esteem and are described as follows:

- Achievement provides an indication of starting a business and growth of a business (Spencer, McClelland \& Spencer, 1992; Robinson et al., 1991; Roberts, 1991).

- Innovation relates to an individual perceiving and implementing things in new ways. This factor is closely associated with creative thinking (Robinson et al., 1991; Kirton, 1976, 1978; Hornaday \& Aboud, 1971).

- Perceived control relates to the degree of influence that an individual has in a situation (Robinson et al., 1991; Rotter, 1966, 1990; Levenson, 1981; Brockhaus, 1976).

- Self-esteem relates to the degree of self-efficacy and confidence that an individual has (Robinson et al., 1991; Crandall, 1973).

An Overview of the Hytti's Model: The case of UWC: The Hytti model was introduced for second year entrepreneurship students at UWC. The model is based on three dimensions as illustrated in table 2 . The model is an action-based entrepreneurship program designed to stimulate change in cognitive mechanisms of the students. These cognitive mechanisms include beliefs, values and attitudes; and have a profound influence on students' perception of their abilities and skills. During the first semester students are introduced to theoretical and practical aspects of starting a business. Curriculum content includes entrepreneurship as a career choice, trait theory, learning about entrepreneurs, business plans, interviewing techniques, presentation skills, competition, group dynamics and finance.

Table 3: Hytti Model of Entrepreneurship

Understanding Becoming more entrepreneurial Becoming an entrepreneur
Entrepreneurship
(a) What do entrepreneurs do?
(a) I need to take responsibility of my learning, career and life.
(b) What is Entrepreneurship?
(b) How do I take responsibility?
(a) Can I become an entrepreneur?
(c) Why are entrepreneurs
(b) How to become an entrepreneur? needed?
(c) How to manage a business?
(d) How many entrepreneurs do we need? 
Assessments are based on the students maintaining weekly journals, term tests, business plan, student peer evaluation and marketing research. The second semester focuses on operating a small business on the campus as well as harvesting the enterprise. The curriculum in this regard involves business plan review, goal setting and success factors, action plans, innovation, personal initiative, micro enterprise operations, exit strategies, harvesting the enterprise and entrepreneurial life strategies. The assessments are based on weekly journals, case studies and final group report. The University provided the students with a micro loan of about USD 90 which is repayable at the end of the project. With own contributions and loans students managed to raise around USD 500. In cases where students incurred losses they were required to repay the seed capital provided by the University. On the other hand, when the businesses were successful they would share real profits. This represents real experience that is unparalleled by traditional approaches.

\section{Results and Discussion}

Results: Table 4 shows the means, standard deviations for both experimental and control groups in a paired sample comparison. Overall, the univariate comparison shows that the mean scores of the experimental group for the variables achievement orientation, innovation, self-esteem and personal control improved between T1 and T2 improved with the exception of self-esteem.

Table 4: Paired Samples - Statistical Comparison between T1 and T2

\begin{tabular}{llllll}
\hline & & Mean & N & Standard Deviation & Standard Error Mean \\
\hline Experimental group & & & & & \\
Pair 1 & Achav1 & 7.9108 & 60 & 0.66397 & 0.08572 \\
& Achav2 & 8.1990 & 60 & 0.81062 & 0.10465 \\
Pair 2 & Inovav1 & 6.4475 & 60 & 0.67938 & 0.09493 \\
& Inovav2 & 6.7183 & 60 & 0.73531 & 0.08771 \\
Pair 3 & Cntlav1 & 6.9846 & 65 & 1.08448 & 0.13451 \\
& Cntlav2 & 7.2462 & 65 & 1.12614 & 0.13968 \\
Pair 4 & Slfav1 & 7.8041 & 63 & 0.94482 & 0.11904 \\
& Slfav2 & 7.4561 & 63 & 0.81451 & 0.10262 \\
Control group & & & & & \\
Pair 1 & Achav1 & 8.2202 & 35 & 0.84552 & 0.14292 \\
& Achav2 & 7.9464 & 35 & 1.08375 & 0.18319 \\
Pair 2 & Inovav1 & 6.5912 & 34 & 1.00178 & 0.17180 \\
& Inovav2 & 6.4338 & 34 & 0.91102 & 0.19362 \\
Pair 3 & Cntlav1 & 7.2525 & 43 & 1.26968 & 0.18109 \\
Pair 4 & Cntlav2 & 7.1794 & 43 & 1.18752 & 0.16644 \\
& Slfav1 & 7.8041 & 38 & 1.02600 & 0.18476 \\
\hline
\end{tabular}

The results of the control group between $\mathrm{T} 1$ and $\mathrm{T} 2$ show a decline of means for all four variables. However, there significant achievement $(\mathrm{p}<.00, \mathrm{~T}=-2.76)$ and innovation $(\mathrm{p}<.00, \mathrm{~T}=2.83)$ in the experimental group. For the control group there significant self-esteem $(\mathrm{p}<.01, \mathrm{~T}=-2.08)$. Therefore, hypotheses $1,3,4$ and 5 are supported while hypothesis 2 is rejected.

Table 5: Paired Samples Test T1-T2

\begin{tabular}{llll}
\hline & T & Df & Significance (two-tailed) \\
\hline Experimental group & & & \\
Pair 1 achav1 \& achav2 & -2.760 & 59 & $0.008^{* *}$ \\
Pair 2 inovav1 \& inovav2 & 2.833 & 59 & $0.006^{* *}$ \\
Pair 3 cntlav1 \& cntlav2 & -1.718 & 64 & 0.091 \\
Pair 4 slfav1 \& slfav2 & 1.425 & 62 & 0.159 \\
Control group & & & \\
Pair 1 achav1 \& achav2 & 1.55 & 34 & 0.13 \\
Pair 2 inovav1 \& inovav2 & -0.696 & 33 & 0.339 \\
\hline
\end{tabular}




\begin{tabular}{llll}
\hline Pair 3 cntlav1 \& cntlav2 & 0.387 & 42 & 0.701 \\
Pair 4 slfav1 \& slfav2 & -2.080 & 37 & $0.044^{*}$ \\
\hline$P<0.05^{*} P<0.01^{* *}$ & & &
\end{tabular}

Table 6 indicates the comparison between the training group and the control group at T2. Achievement, innovation and self-esteem of the training group were found to be significantly higher than for the same variable in the control group, while no significance was found for locus of control between the two groups. Hypothesis 6 was not supported.

Table 6: Comparison between Training Group and Control Group after Training

\begin{tabular}{lllll}
\hline Source & Df & Mean Square & F & Significance \\
\hline Achievement & 1 & 3.493 & 8.574 & $0.004^{* *}$ \\
Control & 1 & 1.449 & 1.449 & 0.170 \\
Innovation & 1 & 1.989 & 5.913 & $0.017^{*}$ \\
Self esteem & 1 & 3.805 & 5.735 & $0.019^{*}$ \\
\hline
\end{tabular}

$P<0.05^{*} P<0.01^{* *}$

Table 7 deals with results relating to the question of whether there are differences between students who have parents who are self-employed and those who are employed concerning the variables achievement, innovation, locus of control and self-esteem. The chi-square test did not show any significant difference between the two groups concerning the variables examined. Hypothesis 7 was not supported.

Table 7: Comparison between Parents of Students who are Entrepreneurs' employed parents, ChiSquare Tests

\begin{tabular}{llll}
\hline & Value & Df & Asymp. Significance (two-sided) \\
\hline Achievement & 42.884 & 32 & 0.95 \\
Innovation & 35.123 & 36 & 0.510 \\
Locus of control & 23.776 & 24 & 0.474 \\
Self esteem & 25.360 & 23 & 0.332 \\
\hline
\end{tabular}

$P<0.05^{*} P<0.01^{* *}$

Discussion: The objective of this research was to investigate how constructs relating to entrepreneurial orientation can be changed through EE at a University Entrepreneurship education. The results indicate that through EE program it is possible to influence achievement, innovation and self-esteem of University students. In terms of the HYTTI model the program was successful as they learnt about Entrepreneurship as well as becoming more entrepreneurial. The participants in the program learnt about Entrepreneurship as the awareness of the discipline was created. In addition, the participants also learnt entrepreneurial skills as well as becoming more entrepreneurial. The findings in this study support similar findings (Gielniek et al., 2015) where action-based entrepreneurship training impacts on action principles and entrepreneurial intentions. The findings also support previous research studies suggesting that Entrepreneurship can be taught and that EE can enhance entrepreneurial skills, aptitudes and attitudes (Ronstadt, 1987; Hisrich, Peters \& Shepherd, 2002; Timmons \& Spinelli, 2004; Siteman, 2004; Green, Katz \& Johannison, 2004). In the application of the Hytti model it is evident that certain variables of entrepreneurial orientation can be increased through an Entrepreneurship training module at a University. Based on the evidence it is possible to improve achievement orientation, innovation and self-esteem of the students. Participants did not only acquire business skills on starting and managing a business (learning about entrepreneurship) but also improved their entrepreneurial orientation (learning about action principles and to become more entrepreneurial) compared to the control group. The training showed an increase of achievement orientation which supports previous research with different groups of entrepreneurs (McClelland, 1986). Hypothesis 6 relates to locus of control was not supported and emphasises the difficulty in changing mind-sets with an intervention.

This also signifies that locus of control being an attitudinal factor, cannot be changed in a relatively short period of time. Hypothesis 5 relates to innovation emphasises that the training was successful and builds onto 
previous research (see Friedrich \& Visser, 2006) in which innovation was improved through a three day training intervention. Hypothesis 4 relating to self-esteem is significant in that the cost of education is very costly in South African. This finding indicates that the training program improved self-esteem of the students in starting and running a business successfully. The evidence also supports the theory relating to the fact that Entrepreneurship training has a positive impact on the targeted group in a University environment. Several scholars have focussed on human capital and highlighted that Entrepreneurship training programs should incorporate action-based content in order to be more effective (Gielniek et al., 2015; Barr et al., 2009; Fiet, 2001; Gorman et al., 1997; Honig, 2004; Oosterbeek et al., 2010; Rasmussen \& Sorheim, 2006). This suggests a shift in contemporary approaches where action knowledge becomes a central factor in curriculum development in entrepreneurship training.

A marked difference between the Hytti and similar models (Gielniek et al., 2015) is the fact that the students did not have a commerce background. The evidence from Gielniek et al. (2015) study suggests that actionregulatory factors are important mediators in the relationship between action-based training and entrepreneurial action. Over the past decade Entrepreneurship research has focused on the role of action and therefore contributes towards the existing literature. Previous studies on drivers of entrepreneurial action have more or less explicitly referred to expectancy-value models to explain entrepreneurial action. For example, theoretical and empirical studies have investigated the role of uncertainty by suggesting that assessments of feasibility and desirability influence entrepreneurial action (McKelvie, Haynie, \& Gustavsson, 2011; McMullen \& Shepherd, 2006). Similarly, scholars have examined value and expectations in the form of images (Mitchell \& Shepherd, 2010), perceptions (Edelman \& Yli-Renko, 2010), or outcome and ability expectations (Cassar, 2010; Koellinger, Minniti, \& Schade, 2007; Townsend et al., 2010). The line of reasoning underlying this research is that more positive values and expectations translate into stronger entrepreneurial goal intentions and eventually lead to entrepreneurial actions (Ajzen, 1991; Kolvereid \& Isaksen, 2006; Krueger, Reilly, \& Carsrud, 2000).

EE using the HYTTI model and entrepreneurial action provide empirical evidence for consideration in future programs aiming at influencing entrepreneurial intention of University students. Other positive relationships were also established between entrepreneurial training and (a) goal setting, (b) action planning, (c), entrepreneurial self-efficacy, and (d) action knowledge. Other findings also suggest that at least with positive entrepreneurial goal intentions people are better motivated and willing to invest into a specific action; and how hard they are willing to perform the action (Ajzen, 1991). This finding is also supported by previous research that provides evidence for the positive effect of goal intentions on action and performance (Baum \& Locke, 2004; Kolvereid \& Isaksen, 2006; Locke \& Latham, 2002). Furthermore, similar findings suggest that individuals who have documented their goals are more likely to start a business when they integrate goal setting with action plans (Frese \& Zapf, 1994; Frese, 2009). Considering this approach, notably the concept of business plans is distinctly different to action plans. Business plans are formal documented plans describing multiple components of the of a business concept (Honig \& Karlsson, 2004). Action plans are mental recreations of typical entrepreneurial actions that specify the what, and how the entrepreneur does things in the business. By specifying the sub-steps and operational details, action plans control and direct the effort that is captured by goal intentions. Action plans thus help to initiate and maintain goal-directed actions (Frese \& Zapf, 1994; Frese, 2009). The concept of action knowledge relates to know-how in the business. Furthermore, action knowledge comprises information about the principles and causal processes involved, and information about anticipated outcomes and consequences of one's actions. Action knowledge influences the efficiency of people's actions: the better and more sophisticated people's action knowledge, the more efficient their actions (Frese \& Zapf, 1994). Believing to be capable of successfully performing entrepreneurial activities increases the likelihood that people will make the decision to engage in entrepreneurial actions (Boyd \& Vozikis, 1994; Gist \& Mitchell, 1992).

As mentioned above action plans are distinct from business plans and are mental simulation of actions. This finding builds onto action theory suggesting that action unfolds in a sequence of forming a goal, developing action plans and executing the action (Frese, 2009; Frese \& Zaph, 1994). Action plans play a major role in the task sequence and has a direct impact on entrepreneurial success albeit that the literature indicates no direct relationship between goal setting and entrepreneurial action (Gollwitzer, 1999; Miller, Galanter \& Pribram, 1960). Action plans bridge this gap and ensure that goals move into actions. Studies involving entrepreneurial 
orientation and action-regulatory variables (self-efficacy, goal setting, action planning, and action knowledge) have additive effects on the training - entrepreneurial intention relationship (Frese \& Zapf, 1994; Frese, 2009).

Implication: University education in Africa is costly and allows a small number of enrolments each year. A significant number of graduates from these Universities remain unemployed raising questions about the cost, effectiveness and relevance of University education. To this end governments introduced regulatory reforms and more focus on Entrepreneurship courses to encourage graduates to start their own businesses; but the question remains as to whether these interventions are effective. Even with the introduction of EE at the Universities the rate of start-up activity remains low. Are Universities doing enough in order to bring about improvements in current EE? The studies have demonstrated through a longitudinal design that the training programs in HEIs in South Africa can be effective Entrepreneurship.

The EE programs implemented in this study demonstrate the importance of achieving three outcomes. Firstly, the purpose was to raise awareness levels of Entrepreneurship. Secondly, the purpose was to impart entrepreneurial skills and thirdly, to facilitate the process of becoming entrepreneurial. Similar approaches demonstrate that an action-based approach must entail practical components in order to influence prevailing mind-sets of students sufficiently for them to see Entrepreneurship as a viable career path. It is a fact that education alone cannot completely prepare individuals to become entrepreneurs but must be complemented by experiential factors discussed in this paper. On the basis of the findings in this study we build a case to consider EE to be an integral part of the curriculum for final year students and emphasise the need to improve the current perceptions that students have on Entrepreneurship. In addition to developing entrepreneurial skills, particularly final year students must consider Entrepreneurship as a viable career through EE. More importantly, as demonstrated in Gielniek et al's (2015) model proved to be highly successful regarding students with non-commerce backgrounds. Against this background and notwithstanding the fact that there are several challenges in the implementation of EE at HEIs, the leadership at HEIs have a key role to play to instil greater entrepreneurial characters amongst students. More effective integration is required between the South African education curriculum at school level and HEIs pertaining to Entrepreneurship. The curriculum in schooling and higher education systems must be realigned with greater focus on Entrepreneurship as a subject choice. The HYTTI model discussed in this paper should be considered as a means of improving current approaches in EE.

As the study suggests entrepreneurial skills should be distinguished from business management skills. This is clearly demonstrated through an action-based focus in Entrepreneurship training. Often business strategies and business plans are included in the content as the core elements in Entrepreneurship training and fail to impart entrepreneurial skills. EE should capacitate students sufficiently that would enable them to progress an idea, process or invention from start to a commercialisation. Course content should focus on entrepreneurial skills and knowledge. The importance of any Entrepreneurship program must be to influence entrepreneurial intentions and emphasise aspects such as self-reliance, creativity and autonomy. This perspective should ideally be developed at high school levels with the aim of influencing entrepreneurial intentions. Universities can play a greater proactive role in stimulating Entrepreneurship as successfully demonstrated in UWC's shop project. Often University graduates including Entrepreneurship graduates fail to convert their skills into a start-up and become job seekers. Therefore Universities need to collaborate with governmental agencies and other tertiary/private institutions in order to support practical training of existing programs that may be integrated in EE. The training model in this study evaluated the training over a period of 12 months and provided evidence that the training is effective in promoting Entrepreneurship. The training increased the level of entrepreneurial orientation.

\section{Conclusion}

EE is important for creating a positive entrepreneurial climate as well as practical skills required for successful Entrepreneurship. Continuous improvement in prevailing pedagogies has an important role in EE. Although current research has focused on pedagogies and curricula, few studies have been conducted on action-based training. Effectiveness of EE is to a large extent related to the facilitator's skills and contemporary working knowledge of effective pedagogies in Entrepreneurship. Considering business 
planning is one the major courses in EE, this study demonstrates consideration for entrepreneurial orientation constructs as a means of influencing entrepreneurial thinking of commerce students. Based on the study and the success of the approach the following can be concluded:

- Influencing the perspective of students by promoting Entrepreneurship as a viable option to becoming a job seeker;

- $\quad$ Presenting students with the necessary business skills to start and run an enterprise;

- Facilitating experiential learning by operating and managing their own businesses on campus;

- Subjecting students to real life examples of typical business problems, needs and constraints;

- Developing successful case studies based on the successful examples of similar student enterprises from previous years

- This program can be taught to students with non-commercial backgrounds (example, medical students, engineering students and science students).

Limitations and future research: Future research should consider longitudinal research designs as a means of determining the effectiveness of training interventions. Another highlight of the study is the fact that the questionnaire was designed for specific application in Africa. This module has been operating for more than four years and the longitudinal approach in assessing the program is unique. It would be useful to conduct follow up research to determine whether students who have attended the training are starting businesses more frequently than those of the control group. This is of particular interest since the students in both contexts come from diverse backgrounds and geographic locations. A limitation of the study is the small size, particularly in the case of UWC.

Recommendations: Future training in Entrepreneurship must be increasingly more practical and entail action-based approaches. The study provides evidence to suggest that achievement, innovation and selfesteem can be used as a starting point to in University EE curricula. In particular, the practical component of EE can include "shop projects" as a means of exposing students to numerous learning areas in Entrepreneurship. The 'shop project' was successfully operated during the second semester and the University recouped all the seed capital paid out to the various student groups. With greater involvement by the private sector, typically local banks and venture capital firms, it may be possible to increase the amount of seed capital to explore more diverse business opportunities. We suggest that Entrepreneurship become a specialised area of study, for example a diploma, degree and post graduate degree in Entrepreneurship. Due to significant drop-out rates in SA Universities we recommend as a minimum that Entrepreneurship be offered as core subjects at an undergraduate level to encourage students to value and to cultivate more appreciation for Entrepreneurship as a career. There should be closer cooperation between faculties and centres of excellence at Universities. For example, students with strong entrepreneurial orientation profiles should be developed further through centres of excellence. Furthermore, the findings in this study can be integrated into shorter EE programs such as vocational training operated through government funded agencies (see Sector Education and Training Authorities). Although the Global Entrepreneurship Monitor study is a very useful study, Africa needs an exclusive study with more direct focus where EE models, particularly in higher education can be compared and developed. Courses such as the ones described in this study should be considered for replication in HEIs in other parts of Africa.

\section{References}

Aiken, L. S. \& West, S. G. (1991). Multiple Regression: Testing and Interpreting Interactions. Newbury Park: Sage.

Ajzen, I. (1991). The theory of planned behavior. Organizational Behavior and Human Decision Processes, $50(2), 179-211$.

Alarape, A. (2008). On the road to institutionalising Entrepreneurship education in Nigerian Universities. International Journal of Management Education, 7(2).

Alarape, A. A. (1999). Entrepreneurship education: Challenges of Nigerian Universities. Social Science Review, 17, 118- 124. 
Åsvoll, H. \& Jacobsen, P.J. (2012). A Case Study: Action Based Entrepreneurship Education How experience problems can be overcome and collaboration problems mitigated. Journal of Entrepreneurship Education, 15, 75-97.

Bandura, A. (1989). Human agency in social cognitive theory. American Psychologist, 44(9), 1175-1184.

Baron, R. A. (2007a). Behavioral and cognitive factors in Entrepreneurship: Entrepreneurs as the active element in new venture creation. Strategic Entrepreneurship Journal, 1(1-2), 167-182.

Baron, R. A. (2007b). Entrepreneurship: A process perspective. In J. R. Baum, M. Frese, \& R. A. Baron (Eds.), The Psychology of Entrepreneurship, 19-39. Mahwah, NJ: Lawrence Erlbaum.

Barr, S. H., Baker, T. \& Markham, S. K. (2009). Bridging the valley of death: Lessons learned from 14 years of commercialization of technology education. Academy of Management Learning \& Education, 8(3), 370-388.

Baum, J. R. \& Locke, E. A. (2004). The relationship of entrepreneurial traits, skill, and motivation to subsequent venture growth. Journal of Applied Psychology, 89(4), 587-598.

Bird, B. \& Schjoedt, L. (2009). Entrepreneurial Behavior: Its Nature, Scope, Recent Research, and Agenda for Future Research. In A. L. Carsrud, \& M. Brännback (Eds.), Understanding the Entrepreneurial Mind: Opening the Black Box: New York, NY: Springer, 327-358.

Bischoff, K. M. \& Dlugosch, T. J. (2013). Action and Action-Regulation in Entrepreneurship: Evaluating a Student Training for Promoting Entrepreneurship. Academy of Management Learning \& Education (in press).

Blenker, P., Dreisler, P., Færgemann, H. M. \& Kjeldsen, J. (2004). Entrepreneurship education and University context. Konferencepapir IntEnt 2004, Napoli. Retrieved September 29, 2006, from http://www.hha.dk/org/cmsdocs/resme/intent04.doc

Boyd, N. G. \& Vozikis, G. S. (1994). The influence of self-efficacy on the development of entrepreneurial intentions and actions. Entrepreneurship Theory and Practice, 18(4), 63-77.

Brandstatter, V., Heimbeck, D., Malzacher, J. T. \& Frese, M. (2003). Goals need implementation intentions: The model of action phases tested in the applied setting of continuing education. European Journal of Work and Organizational Psychology, 12(1), 37-59.

Braukmann, U. (2000). Fostering of entrepreneurships by Universities - Outlines of an entrepreneurship education within the scope of the 'Bizeps Project'. Proceedings of the 2000 USASBE Annual National Conference: The entrepreneurial millennium, San Antonio, Texas, February 16 - 19.

Brijlal, P. (2011). Entrepreneurial perceptions and knowledge: A survey of final year University students. African Journal of Business Management, 5(3), 818-825.

Brockhaus, R. (1976). Locus of control and risk-taking propensity as entrepreneurial characteristics. Unpublished doctoral dissertation. Washington University, St. Louis.

Cassar, G. (2010). Are individuals entering self-employment overly optimistic? An empirical test of plans and projections on nascent entrepreneur expectations. Strategic Management Journal, 31(8), 822-840.

Crandall, R. (1973). Measurement of self-esteem and related constructs. In: J. Robinson \& P. Shaver (Eds), Measurement of social psychological attitudes. Ann Arbor: University of Michigan.

Crotty, M. (2003). The Foundations of Social Research: Meaning and Perspectives in the Research Process, London: Sage Publications, 3rd edition, 10.

Davidsson, P. \& Honig, B. (2003). The role of social and human capital among nascent entrepreneurs. Journal of Business Venturing, 18(3), 301-331.

Edelman, L. F. \& Yli-Renko, H. (2010). The impact of environment and entrepreneurial perceptions on venture-creation efforts: Bridging the discovery and creation views of Entrepreneurship. Entrepreneurship Theory and Practice, 34(5), 833-856.

Edelman, L. F., Manolova, T. S. \& Brush, C. G. (2008). Entrepreneurship education: Correspondence between practices of nascent entrepreneurs and textbook prescriptions for success. Academy of Management Learning \& Education, 7(1), 56-70.

Fiet, J. O. (2001). The pedagogical side of Entrepreneurship theory. Journal of Business Venturing, 16(2), 101117.

Frese, M. (2009). Toward a psychology of Entrepreneurship - An action theory perspective. Foundations and Trends in Entrepreneurship, 5(6), 437-496.

Frese, M., Krauss, S. I., Keith, N., Escher, S., Grabarkiewicz, R., Luneng, S. T. \& Friedrich, C. (2007). Business owners' action planning and its relationship to business success in three African countries. Journal of Applied Psychology, 92(6), 1481-1498. 
Frese, M., Bausch, A., Schmidt, P., Rauch, A. \& Kabst, R. (2012). Evidence-based Entrepreneurship: Cumulative Science, Action Principles, and Bridging the Gap Between Science and Practice. Foundations and Trends in Entrepreneurship, 8(1), 1-62

Frese, M., van Gelderen, M. \& Ombach, M. (2000). How to plan as a small scale business owner: Psychological process characteristics of action strategies and success. Journal of Small Business Management, 38(2), $1-18$.

Frese, M. \& Zapf, D. (1994). Action as the core of work psychology: A German approach. In H. C. Triandis, M. D. Dunnette, \& L. M. Hough (Eds.), Handbook of Industrial and Organizational Psychology, 4, 271-340. Palo Alto, CA: Consulting Psychologists Press.

Friedrich, C. \& Visser, K. 2006. Building Human Capital in Difficult Environments: An Empirical Study of Entrepreneurship Education, Self-esteem, and Achievement in South Africa, in Craig S. Galbraith, Curt H. Stiles (ed.) Developmental Entrepreneurship: Adversity, Risk, and Isolation (International Research in the Business Disciplines, 5) Emerald Group Publishing Limited, 355 - 378.

Gielniek, M. M., Frese, M., Kahara-Kawuki, A., Katono, I. W., Kyejjusa, S., Ngoma, M., Munene, J., NamatovuDawa, R., Nansubuga, F., Orobia, L., Sejjaaka, S., Sserwanga, A., Walter, T., Bischoff, K. M. \& Dlugosch, T. J. Gielnik, M. M., Frese, M., Kahara-Kawuki, A., Wasswa Katono, I., Kyejjusa, S., Munene, J., Muhammed, N., Namatovu-Dawa, R., Nansubuga, F., Orobia, L., Oyugi, J., Sejjaaka, S., Sserwanga, A., Walter,T. (2015). Action and Action-Regulation in Entrepreneurship: Evaluating a Student Training for Promoting Entrepreneurship. Academy of Management Learning \& Education, 14(1), 69-94.

Gist, M. E. \& Mitchell, T. R. (1992). Self-efficacy: A theoretical analysis of its determinants and malleability. Academy of Management Review, 17(2), 183-211.

Gollwitzer, P. M. (1999). Implementation intentions: Strong effects of simple plans. American Psychologist, 54(7), 493-503.

Gorman, G., Hanlon, D. \& King, W. (1997). Some research perspectives on Entrepreneurship education, enterprise education and education for small business management: a ten-year literature review. International Small Business Journal, 15(3), 56-77.

Guba \& Lincolin. (1989). Fourth Generation Evaluation. London: SAGE Publications, 83.

Hermans, H. (1970). A questionnaire measure of achievement motivation. Journal of Applied Psychology, 54(4), $353-363$.

Green, P., Katz, J. \& Johannison, B. (2004). Entrepreneurship education. Academy of Management Learning and Education, 3(3), 238-241.

Hills, G. E., Lumpkin, G. T. \& Singh, R. P. (1997). Opportunity recognition: perceptions and behaviors of entrepreneurs. In P. D. Reynolds, W. D. Bygrave, N. M. Carter, P. Davidsson, W. B. Gartner, C. M. Mason, \& P. P. McDougall (Eds.), Frontiers of Entrepreneurship Research, 168-182. Babson Park, MA: Babson College.

Hisrich, R. D., Peters, R. P. \& Shepherd, D. A. (2002). Entrepreneurship. Boston: McGraw-Hill/Irwin.

Honig, B. (2004). Entrepreneurship education: Toward a model of contingency-based business planning. Academy of Management Learning \& Education, 3(3), 258-273.

Honig, B. \& Karlsson, T. (2004). Institutional forces and the written business plan. Journal of Management, $30(1), 29-48$.

Hornaday, J. \& Aboud, J. (1971). Characteristics of successful entrepreneurs. Personnel psychology, 24(2), 141 $-153$.

Jenvey, N. (2015). Calls for entrepreneurship education in universities. Paper presented at the third Annual International Conference on Innovation and Entrepreneurship held in Durban, South Africa. Retrieved from http://www.universityworldnews.com/article.php?story=2015032413133496.

Kalitanyi, V. \& Visser, K. (2010). African immigrants in South Africa: job takers or job creators? SAJEMS, 4, 376-390.

Kiggundu, M. (2002). Entrepreneurs and entrepreneurship in Africa: What is known and what needs to be done. Journal of Developmental Entrepreneurship, 7(3), 239-257.

Kirton, M. (1976). Adaptors and innovators: A description and measure. Journal of Applied Psychology, 61(5), $622-629$.

Kirton, M. (1978). Have adaptors and innovators equal levels of creativity. Psychological Reports, 42, 695 698.

Koellinger, P., Minniti, M. \& Schade, C. (2007). I think I can, I think I can: Overconfidence and entrepreneurial behavior. Journal of Economic Psychology, 28(4), 502-527. 
Kolvereid, L. \& Isaksen, E. (2006). New business start-up and subsequent entry into self-employment. Journal of Business Venturing, 21(6), 866-885.

Krauss, S. I., Frese, M., Friedrich, C. \& Unger, J. M. (2005). Entrepreneurial orientation: A psychological model of success among southern African small business owners. European Journal of Work and Organizational Psychology, 14(3), 315-344.

Krueger, N. F., Reilly, M. D. \& Carsrud, A. L. (2000). Competing models of entrepreneurial intentions. Journal of Business Venturing, 15(5-6), 411-432.

Latham, G. P., Saari, L. M., Pursell, E. D. \& Campion, M. A. (1980). The situational interview. Journal of Applied Psychology, 65(4), 422-427.

Levenson, H. (1981). Differentiating among internality, powerful others and chance. In: H. Lefcourt (Ed.), Research with the locus of control construct: Assessment methods, Vol. 1. New York: Academic Press.

Locke, E. A. \& Latham, G. P. (2002). A theory of goal setting and task performance. Englewood Cliffs, NJ: Prentice-Hall.

Martin, B., McNally, J. J. \& Kay, M. J. (2013). Examining the formation of human capital in Entrepreneurship: A meta-analysis of Entrepreneurship education outcomes. Journal of Business Venturing, 28, 211-224.

McClelland, D. (1965). Need for achievement and Entrepreneurship: A longitudinal study. Journal of Personality and Social Psychology, 1(4), 389 - 392.

McClelland, D. (1986). Characteristics of successful entrepreneurs. Journal of Creative Behaviour, 21(3), 219 233.

McKelvie, A., Haynie, J. M. \& Gustavsson, V. (2011). Unpacking the uncertainty construct: Implications for entrepreneurial action. Journal of Business Venturing, 26(3), 273-292.

McMullen, J. S. \& Shepherd, D. A. (2006). Entrepreneurial action and the role of uncertainty in the theory of the entrepreneur. Academy of Management Review, 31(1), 132-152.

Mentoor, E. \& Friedrich, C. (2007). Is entrepreneurial education at South African Universities successful? An empirical example. Industry and Higher Education, 21, 231-232.

Miller, G. A., Galanter, E. \& Pribram, K. H. (1960). Plans and the structure of behavior. London: Holt.

Mitchell, J. R. \& Shepherd, D. A. (2010). To thine own self be true: Images of self, images of opportunity, and entrepreneurial action. Journal of Business Venturing, 25(1), 138-154.

Mumford, M. D., Schultz, R. A. \& Van Doorn, J. R. (2001). Performance in planning: Processes, requirements, and errors. Review of General Psychology, 5(3), 213-240.

Neck, H. M. \& Greene, P. G. (2011). Entrepreneurship education: Known worlds and new frontiers. Journal of Small Business Management, 49(1), 55-70.

Nicolaides, A. (2011). Entrepreneurship- the role of Higher Education in South Africa. Educational Research, 2(4)1043-1050.

Oosterbeek, H., van Praag, C. M. \& Ijsselstein, A. (2010). The impact of Entrepreneurship education on Entrepreneurship skills and motivation. European Economic Review, 54(3), 442-454.

Preacher, K. J. \& Hayes, A. F. (2008). Asymptotic and resampling strategies for assessing and comparing indirect effects in multiple mediator models. Behavior Research Methods, 40(3), 879-891.

Pittaway, L. \& Cope, J. (2007). Entrepreneurship education: A systematic review of the evidence. International Small Business Journal, 25(5), 479-510.

Rasmussen, E. A. \& Sorheim, R. (2006). Action-based Entrepreneurship education. Journal of Technovation, 26, 185-194.

Roberts, E. (1991). Entrepreneurs in high technology. London: Oxford University Press.

Robinson, P., Stimpson, D. V., Huefner, J. \& Hunt, H. (1991). Entrepreneurial research on student subjects does not generalise to real world entrepreneurs. Journal of Small Business Management, 29, 42 - 50.

Ronstadt, R. (1987). The educated entrepreneurs. A new era of entrepreneurial education is beginning. American Journal of Small Business, 11(4), 37 - 53.

Ronstadt, R. (1990). The educated entrepreneurs: A new era of entrepreneurial education is beginning. In C. A. Kent (Ed.), Entrepreneurship education: Current developments, future directions (pp. 69-88). New York: Quorum Books.

Rotter, J. (1990). Internal versus external control of reinforcement. American Psychologist, 45, 489 - 493.

Rotter, J. (1966). Generalised expectations for internal versus external control of reinforcement. Psychological monographs. General and Applied, 80(1), 1 - 27.

Rwigema, R. \& Venter. R. (2004). Advanced Entrepreneurship, Oxford University Press, Cape Town. 
Shane, S. (2000). Prior knowledge and the discovery of entrepreneurial opportunities. Organization Science, 11(4), 448-469.

Shane, S., Locke, E. A. \& Collins, C. J. (2012). Entrepreneurial motivation. Human Resource Management Review, 13(2), 257-279.

Singer, S., Amoros, J. E. \& Moska, D. (2014). Global Entrepreneurship Monitor 2014 Global Report. Retrieved 5 Mar 2015, http://gemconsortium.org/report

Siteman, A. (2004). Can entrepreneurship be taught? Reflections on the MIT experience. Online, http://www.esmas.com/emprendedores/startups/eresemprendedor/401446.html. February 20, 2005.

Souitaris, V., Zerbinati, S. \& Al-Laham, A. (2007). Do Entrepreneurship programmes raise entrepreneurial intention of science and engineering students? The effect of learning, inspiration and resources. Journal of Business Venturing, 22(4), 566-591.

Spencer, L., McClelland, D. \& Spencer, S. (1992). Competency assessment methods. Boston: Hay-McBer Research Press.

Statistics South Africa. (2015). Quarterly Labour Force Survey. Pretoria

Streeter, D. H., Jaquette, J. P., Jr. \& Hovis, K. (2002). University-wide Entrepreneurship education: Alternative models and current trends (Working paper 2002-02). Ithaca, NY: Cornell University, Department of Applied Economics and Management. Retrieved October 2, 2006, from http://epe.cornell.edu/downloads/WP_2002_final.PDF

Timmons, J. \& Spinelli, S. (2004). New venture creation: Entrepreneurship for the $21^{\text {st }}$ century. Boston: Irwin McGraw-Hill.

Townsend, D. M., Busenitz, L. W. \& Arthurs, J. D. (2010). To start or not to start: Outcome and ability expectations in the decision to start a new venture. Journal of Business Venturing, 25(2), 192-202.

Ucbasaran, D., Westhead, P. \& Wright, M. (2008). Opportunity identification and pursuit: Does an entrepreneur's human capital matter? Small Business Economics, 30(2), 153-173.

Unger, J. M., Rauch, A., Frese, M. \& Rosenbusch, N. (2009). Human capital and entrepreneurial success: A meta-analytical review. Journal of Business Venturing, 26(3), 341-358.

Urban, B. \& Congo, K. (2015). The relevance of human capital to firm performance: A focus on the retail industry in Kinshasa, Democratic Republic of Congo. Independent Research Journal in Management Sciences, 15(1).

Van Wyk, R., Boschoff, A. B. \& Owen, J. H. (1999). Construct validity of psychometric instruments developed in the United States when applied to professional people in South Africa. South African Journal of Economic and Management Sciences, SS1 (Special Issue), 1 - 72.

Wickham, P. (2004). Strategic Entrepreneurship. Harlow, England: Pearson Education. 